\title{
Role of Environmental Variables in the Transport of Microbes in Stormwater
}

\author{
Rupak Aryal 1,2,3,4,*, Jatinder P. S. Sidhu ${ }^{5}$, Meng Nan Chong ${ }^{6}$, Simon Toze ${ }^{5}$, Wolfgang Gernjak ${ }^{3,4,7,8}$ \\ and Bandita Mainali ${ }^{2}$
}

1 Faculty of Engineering, University of Technology Sydney (UTS), P.O. Box 123, Broadway, Sydney, NSW 2007, Australia

2 School of Engineering and Mathematical Sciences, La Trobe University, Flora Hill Bendigo, Melbourne, VIC 3552, Australia; b.mainali@ltu.edu.au

3 Cooperative Research Centre for Water Sensitive Cities, Melbourne, VIC 3800, Australia; w.gernjak@awmc.edu.au

4 Advanced Water Management Centre, University of Queensland, Brisbane, QLD 4072, Australia

5 CSIRO, 41 Boggo Road Dutton Park, Brisbane, QLD 4102, Australia; Jatinder.Sidhu@csiro.au (J.P.S.S.); Simon.Toze@csiro.au (S.T.)

6 School of Engineering, Chemical Engineering Discipline, Monash University Malaysia, Jalan Lagoon Selatan, Bandar Sunway, Selangor DE 47500, Malaysia; meng.nan.chong@monash.edu.au

7 Catalan Institution for Research and Advanced Studies (ICREA), 08010 Barcelona, Spain

8 Catalan Institute for Water Research (ICRA), 17003 Girona, Spain

* Correspondence: rupak.aryal@uts.edu.au

Citation: Aryal, R.; Sidhu, J.P.S.; Chong, M.N.; Toze, S.; Gernjak, W.; Mainali, B. Role of Environmental Variables in the Transport of Microbes in Stormwater. Water 2021, 13, 1146. https://doi.org/10.3390/w13091146

Academic Editors: Constantinos V. Chrysikopoulos and Abasiofiok Mark Ibekwe

Received: 27 January 2021

Accepted: 13 April 2021

Published: 21 April 2021

Publisher's Note: MDPI stays neutral with regard to jurisdictional claims in published maps and institutional affiliations.

Copyright: (c) 2021 by the authors Licensee MDPI, Basel, Switzerland. This article is an open access article distributed under the terms and conditions of the Creative Commons Attribution (CC BY) license (https:// creativecommons.org/licenses/by/ $4.0 /)$
Abstract: Microbial pathogens present in stormwater, which originate from human sewage and animal faecal matters, are one of the major impediments in stormwater reuse. The transport of microbes in stormwater is more than just a physical process. The mobility of microbes in stormwater is governed by many factors, such as dissolved organic matter, cations, $\mathrm{pH}$, temperature and water flow. This paper examined the roles of three environmental variables, namely: dissolved organic matter, positive cations and stormwater flow on the transport of two faecal indicator bacteria (FIB), Enterococcus spp. and Escherichia coli. Stormwater runoff samples were collected during twelve wet weather events and one dry weather event from a medium density residential urban catchment in Brisbane. Enterococcus spp. numbers as high as $3 \times 10^{4} \mathrm{cfu} / 100 \mathrm{~mL}$ were detected in the stormwater runoff, while Escherichia coli numbers up to $3.6 \times 10^{3} \mathrm{cfu} / 100 \mathrm{~mL}$ were observed. The dissolved organic carbon (DOC) in the stormwater samples was in the range of $2.2-5.9 \mathrm{mg} / \mathrm{L}$ with an average concentration of $4.5 \mathrm{mg} / \mathrm{L}$ in which the hydrophilic carbon constituted the highest mass fraction of $60-80 \%$. The results also showed that the transport of FIB in stormwater was reduced with an increasing concentration of the hydrophilic organic fraction, especially the humic fraction. On the contrary, the concentration of trivalent cations and stormwater flow rate showed a positive correlation with the FIB numbers. These findings indicated the potentiality to make a good use and measurement of simple environmental variables to reflect the degree of microbe transport in stormwater from residential/suburban catchments.

Keywords: stormwater; flow rate; microbes; dissolved organic matter; humic acid; metals

\section{Introduction}

Stormwater harvesting and reuse from urban catchments has been identified as a viable strategy for reducing water demand through both potable and non-potable water augmentation. However, a wide range of pollutants, such as pathogens and chemicals from non-point sources, are the major challenges posed for its treatment and reuse [1] and may cause serious health risks to human beings [2-4].

Microbes in urban stormwater originate from both point and diffuse sources, including those from animal and human faecal pollution $[2,5,6]$. The urban stormwater runoff 
can mobilise and transport microbial pathogens from various non-point sources to surface water bodies, such as rivers, lakes and creeks. The transport processes that govern the movement of microbial pathogens are described by adsorption and/or desorption as well as hydrological processes [7]. Thus, the transport of microbes involves several environmental factors, such as dissolved organic matter, cations, $\mathrm{pH}$ and temperature, while the hydrological processes include rainfall intensity, duration and flow rate [8,9].

Microbes are usually negatively charged in a neutral $\mathrm{pH}$ regime [10,11]. Additionally, since most natural surfaces are negatively charged at the $\mathrm{pH}$ levels found in the environment, repulsion would be expected as a result of interaction between natural surfaces and their associated double layer counterions [11]. Humic substances that constitute half of the dissolved organic matter, which are the fraction of organic matter smaller than $0.45 \mu \mathrm{m}$ in size, are also negatively charged when present in stormwater. Previously, it was reported that a small increase in hydrophobic organic material could significantly delay the transport of microbes [12].

To date, a number of studies have examined the possible correlations between meteorological data, such as rainfall intensity, rainfall volume and flow rate, and the concentration of microbes in surface water $[13,14]$. For a long time, indicator bacteria of faecal contamination, such as Escherichia coli and Enterococci spp., have been used to assess microbial quality of water sources [15]. Such faecal indicator bacteria (FIB) can also be used to assess the transport of microbes in a watershed during different hydrological events and help to assess the risk of microbiological pollution or predict how they are being transported during storm events, as well as inform the design of water-sensitive urban design (WSUD) units to meet specific end-water reuse requirements.

Numerous studies have been conducted on surface water samples to reveal multiple relationships between microbial concentrations in surface water and various catchment and hydrological variables [16-19]. Stormwater runoff is a dynamic process, and the pollutants' concentrations may vary within one storm event and among different storm events. In any event, a similar stormwater flow may result in different pollutant concentrations and loads $[1,20,21]$. Therefore, the various studies conducted on surface runoff are limited and they are typically performed on a single grab sample or during a single event, which could be too limited to identify the microbe transport span and concentration range [22]. Several studies have discussed the transport of microbes in different runoff events but the correlation was mostly confined to total suspended solids $[18,23,24]$. Suspended solids can become a physical transport carrier for microbes in stormwater, but the physical attachment and/or adhesion of microbes to suspended solids depends on other competing water quality factors, such as humic acid and metals $[17,25,26]$. Tacit mobility and partitioning of microbes in stormwater runoff into freely suspended and other carrier media, such as solid particles, are not well understood, with contrasting empirical observations that vary widely in the open literature [27].

There are some studies on the transport of microbes in the presence of organic matter, metal ions and flow rate $[28,29]$. However, these studies are confined to a laboratory scale and conducted with column experiments. Thus, these studies are not representative and do not fully mimic the dynamics of open environment surface water flow. A review of the literature [3,30-32] showed a significant knowledge gap pertaining to the roles of environmental variables in microbe transport in stormwater from an urban catchment and knowledge of the key factors that control the transfer of microbes in stormwater is quite limited.

To our knowledge, there has been no previous attempts to determine the impact of dissolved organic matter (DOM), metal ions and flow rate on the concentration of microbial populations during stormwater runoff events.

Thus, the aims of this study were to evaluate the possible relationships and usefulness of environmental parameters such as dissolved organic matter, metal ions and stormwater flow to the transport of FIB of E. coli and Enterococcus spp. that could be useful as indicators of microbial pathogen presence or prevalence in a semi-urban watershed. It is anticipated 
that the outcomes of this research can make a good use of environmental parameters as useful predictors of microbial pathogens. Furthermore, the results can also be used to make informed decisions on the construction of best management practices (BMPs) to effectively control the presence of microbes in stormwater as well as facilitate the development of more comprehensive hydrological models with an increased capacity to estimate and predict microbiological parameters.

\section{Materials and Methods}

\subsection{Sample Collection}

Stormwater samples were collected from a stormwater drain gathering runoff from a catchment covering an area of $2.9 \mathrm{~km}^{2}$ from March to May 2011 over 12 storm events (Figure 1) in Fitzgibbon, South East Queensland using three autosamplers (ISCO 6700 series, Isco Inc., Lincoln, NE, USA). The catchment was a medium-density residential urban catchment where the impervious surface constitutes about $30 \%$ of the total area. A flow-proportional sampling mode (collected at a certain runoff volume interval) was chosen to collect sets of samples in all events. The autosamplers were programmed to be triggered simultaneously to collect $20 \mathrm{~L}$ in high-density polyethylene (HDPE) containers in each step. A set of 24 such containers was placed in a shed to collect the samples. In total, 13 samples were collected, including one sample from a dry weather period and the rest from stormwater events. The stormwater flow was measured with a submersible Argonaut Flow Doppler (Thermo Fisher Sci, Melbourne, Australia). The samples were collected when stormwater flow exceeded the dry weather flow by $20 \%$ and stopped when the flow returned to less than $20 \%$ of the dry flow. A remote telemetry system was established to notify the research team about the sampling in each container via SMS. After sample collection, the containers were transported back to the laboratory. A set of samples collected in each event was mixed to represent the event mean concentration. In two storm events, the flow proportion samples (at the beginning and at the end of the event) were also analysed in addition to the event mean concentration (EMC). To avoid contamination of the sampling containers, they were cleaned using sodium hypochlorite solution (10\%) and rinsed with ultra-pure water (MilliQ system, Millipore, Melbourne, Australia) in the laboratory before replacing the filled HDPE containers at the site.

\subsection{E. coli and Enterococcus spp.}

Quantification of faecal indicator bacteria (FIB) (E. coli and Enterococcus spp.) was performed by the standard membrane filtration method [33]. One milliliter and $10 \mathrm{~mL}$ water samples were filtered through $0.45 \mu \mathrm{m}$ nitrocellulose (Millipore, Melbourne, Australia) filters $\left(47 \mathrm{~mm}\right.$ ) in triplicate and placed on Chromocult ${ }^{\mathrm{TM}}$ coliform agar (Merck, Darmstadt, Germany) and Chromocult ${ }^{\mathrm{TM}}$ Enterococci agar (Merck, Darmstadt, Germany) for E. coli and, Enterococci enumeration, respectively. The plates were incubated at $37^{\circ} \mathrm{C}$ overnight and then typical colonies from plates with colony numbers $<100$ were counted to determine the average number of colony-forming units (cfu/100 mL). E. coli ATCC 9637 and E. faecalis ATCC 19433 was used as a positive control in this study. In order to ensure quality control, field blanks and negative controls (sterile MilliQ water) were also processed with each FIB quantitation run. To confirm the presence of E. coli and Enterococci, typical well-isolated presumptive E. coli and Enterococci colonies (1-5 per dilution) were picked with a $20 \mu \mathrm{L}$ pipette tip from the Chromocult ${ }^{\mathrm{TM}}$ coliform agar and Chromocult ${ }^{\mathrm{TM}}$ Enterococci agar plates, respectively. Colonies were suspended in $200 \mu \mathrm{L}$ of sterile distilled water by vortexing. DNA was extracted from the cell pellets using an InstaGene ${ }^{\mathrm{TM}}$ Matrix according to the manufacturer's instructions (Bio-Rad Laboratories, Sydney, Australia). Presumptive E. coli and Enterococci isolates were confirmed by PCR as described previously [2,4]. 


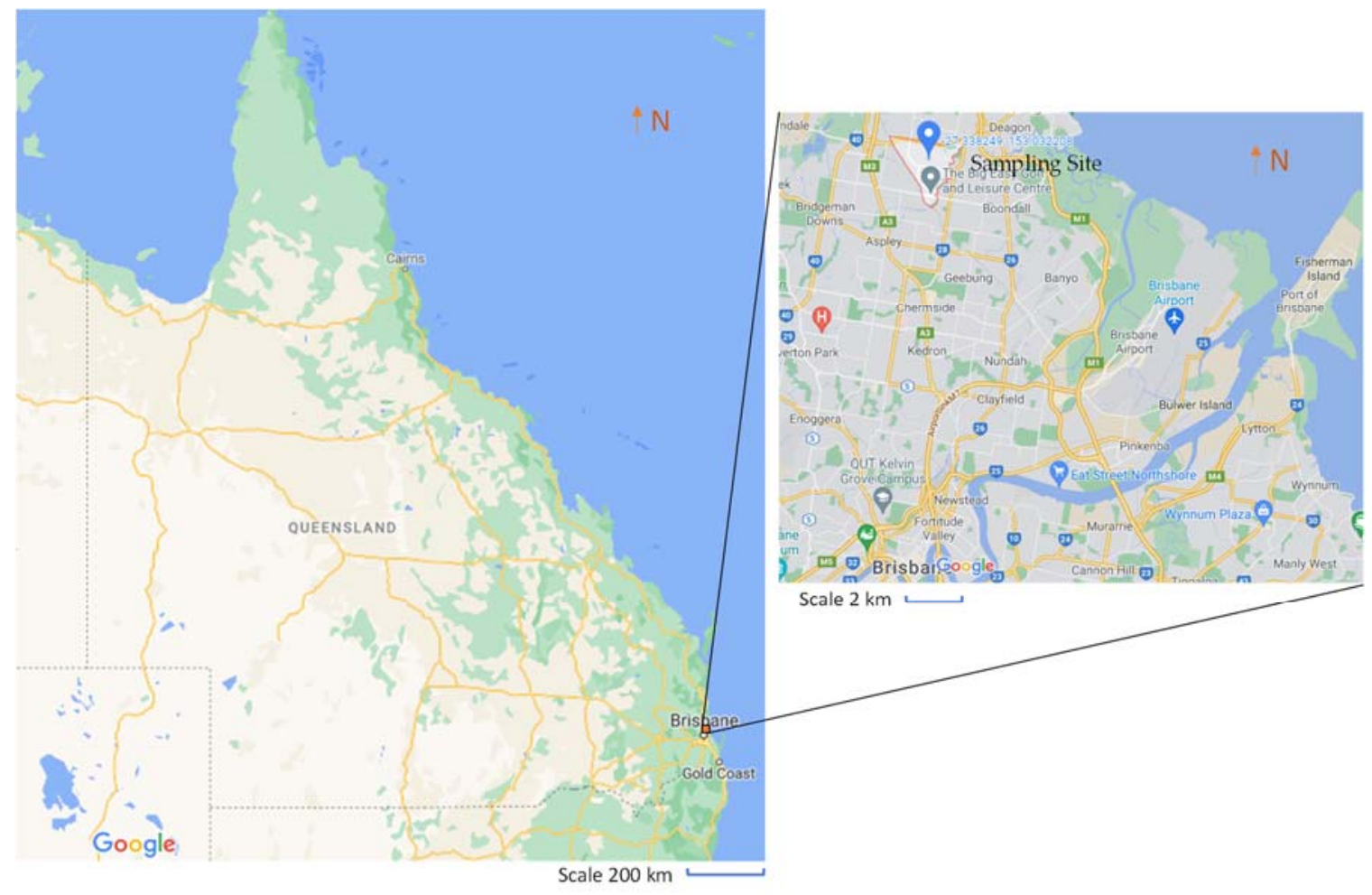

Figure 1. Queensland, Australia map and sampling site (adopted from Google Maps).

\subsection{Dissolved Organic Matter}

The stormwater samples were collected in the field during dry (i.e., no flow) conditions as well as during storm events. The dry condition sample was collected by simple grab sampling whereas the wet event samples were collected using the autosampler as described above. After sampling, the samples were immediately brought back to the laboratory after the storm had stopped. The sample was then passed through $0.45 \mu \mathrm{m}$ glass fibre filters (GF/C Whatman, UK) and analysed by liquid size exclusion chromatography with organic carbon detection (LC-OCD, DOC Labor, DOC Labor Gmbh, Karlsruhe, Germany) for dissolved organic fractions.

The composite stormwater samples were analysed using a UV spectrometer (Varian Cary 50 Bio, Varian Inc, Palo Alto, CA, USA). The instrument was operated at bandwidth $1 \mathrm{~nm}$, with a quartz cell of $10 \mathrm{~mm}$ path length, scanning wavelengths of 190 to $400 \mathrm{~nm}$ and at a scanning speed of $190 \mathrm{~nm} / \mathrm{min}$ (slow).

The LC-OCD instrument measured hydrophilic and hydrophobic fractions. In the hydrophilic fraction, it distinguishes biopolymers, humic substances, building blocks and low molecular weight organics. The LC-OCD system consists of an HW-50S column (GROM Analytik + HPLC GmbH, Herrenberg, Germany) and an organic carbon detector based on the Grantzel thin film reactor. One $\mathrm{mL}$ stormwater samples were injected into the instrument and eluted with the eluent mixture containing $2.5 \mathrm{~g} / \mathrm{L} \mathrm{KH}_{2} \mathrm{PO}_{4}$ and $1.5 \mathrm{~g} / \mathrm{L}$ $\mathrm{Na}_{2} \mathrm{HPO}_{4} 2 \mathrm{H}_{2} \mathrm{O}$ at a flow rate of $1.1 \mathrm{~mL} / \mathrm{min}$. Suwannee River Humic Acids Standard II (Catalog \# 2S101H, IHSS - International Humic Substances Society, Denver, CO, USA) and Suwannee River Fulvic Acids Standard II (Catalog \# 2S101F, IHSS-International Humic Substances Society, Denver, CO, USA) were analysed as reference standards. Potassium nitrate and potassium cyanide were used to calibrate the nitrogen detector.

\subsection{Cation Measurement}

Three trivalent metals, $\mathrm{Al}, \mathrm{Fe}$ and $\mathrm{Mn}$, which are abundant in soil, were measured in filtered water samples by using inductively coupled plasma mass spectrometry (ICP/MS- 
Perkin Elmer, Waltham, MA, USA). Analyses were performed in triplicate for all the samples and the median was taken for the result and discussion.

\section{Results}

\subsection{Faecal Indicator Occurrence during Storm Events}

Stormwater samples, event mean concentration and flow proportion, mentioned above, were analysed for faecal indicator bacteria (FIB). Figure 2 shows the number of E. coli and Enterococcus spp. observed in one dry weather sample and in wet weather event mean concentration samples. Both E. coli and Enterococcus spp. numbers were significantly higher (more than twofold in many events) during the wet weather period than the dry period, when E. coli and Enterococcus spp. numbers were $\sim 10^{2} / 100 \mathrm{~mL}$. This result suggested that during the runoff event, the FIB were washed off and hence increased in concentration in the runoff water. High FIB numbers observed after the rain events were also similar to what had been previously reported in the literature. Tiefenthaler, et al. [34] observed significant FIB loads during wet weather flow in a southern Californian stream. Similarly, McCarthy, Hathaway, Hunt and Deletic [18] observed an increase in FIB concentrations in wet weather periods during different events in different catchments across Melbourne, Australia. It was said that stormwater may have washed off the surfacedeposited microbes along with other pollutants and drained them into receiving water bodies. The ranges of FIB in stormwater reported in this study are in agreement with the reported numbers in the literature $[35,36]$. A large variation in FIB numbers in stormwater events indicates that each event is significantly different from the others. This emphasises the need to garner knowledge of the roles of the environmental variables that influence FIB mobility to construct best management practices (BMPs) for recycling and reuse.

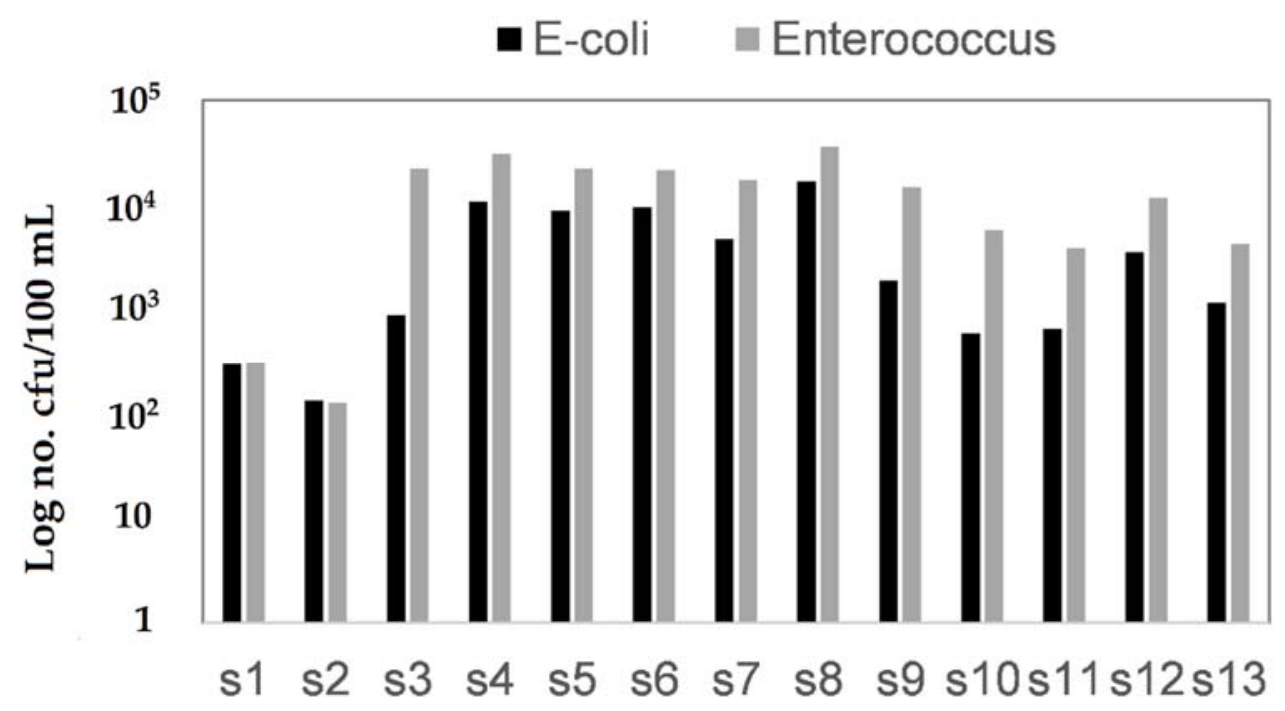

Figure 2. E. coli and Enterococcus spp. numbers in stormwater samples. S1 is dry weather sample and S2-S13 are wet weather samples collected between March 2011 to April 2012.

\subsection{Dissolved Organic Matter Concentration}

Dissolved organic matter (DOM) is defined as the natural organic matter (NOM) fraction that passes through a $0.45 \mu \mathrm{m}$ filter [37]. There appears to be an increasing interest in DOM, not only in total content but also in its chemical composition, since DOM comprises hundreds of molecules and chemical structures [38,39]. The fractions in DOM mainly comprise humic/fulvic acid, polysaccharides, polyphenols, proteins, lipids and other heterogeneous organic molecules [40,41]. The dominant fraction, the humic/fulvic fraction, is negatively charged. It is believed that the interaction of humic fractions and microbes occurs mainly through adsorption $[11,42,43]$. 
A good correlation between bacterial abundance and dissolved organic carbon (DOC) has been reported previously [26]. Some researchers have documented the interaction between two surface properties, the charge and hydrophobicity/hydrophilicity of the microbes and dissolved organic matter, to be important for the transport of microbes [11,42, $44,45]$. However, as the characterisation of dissolved organic matter is complex, studies on correlating organic matter fractions and microbe abundance are, to date, limited to either hydrophilic/hydrophobic or humic materials.

Figure 3 reveals the size distribution of DOM determined by liquid chromatography with organic carbon detection for six events to illustrate the variability of DOM composition (only six out of 13 events are shown to minimise congestion in the figure). The graph indicates that there was a significant variation in the DOM constituents in events. The DOM ranged between 2.19 and $7.8 \mathrm{mg} / \mathrm{L}$ with an average of $4.4 \mathrm{mg} / \mathrm{L}$ in wet weather events and $7.73 \mathrm{mg} / \mathrm{L}$ during dry weather conditions. The first dry weather sample taken on 7 March 2011 (grab sample) had the highest DOC concentration. It was assumed that stagnation in the flow caused high DOC in the drain. During the dry weather period, the humic fraction level was almost two times higher compared to the wet weather period. In wet weather events, the humic fractions were in the range of 643 to $6243 \mathrm{mg} / \mathrm{L}$ with an average of $2639 \mathrm{mg} / \mathrm{L}$. From a contribution ratio perspective, the humic fraction was $54 \%$ in the dry weather period, whereas it ranged between 29 and $45 \%$ in wet weather events.

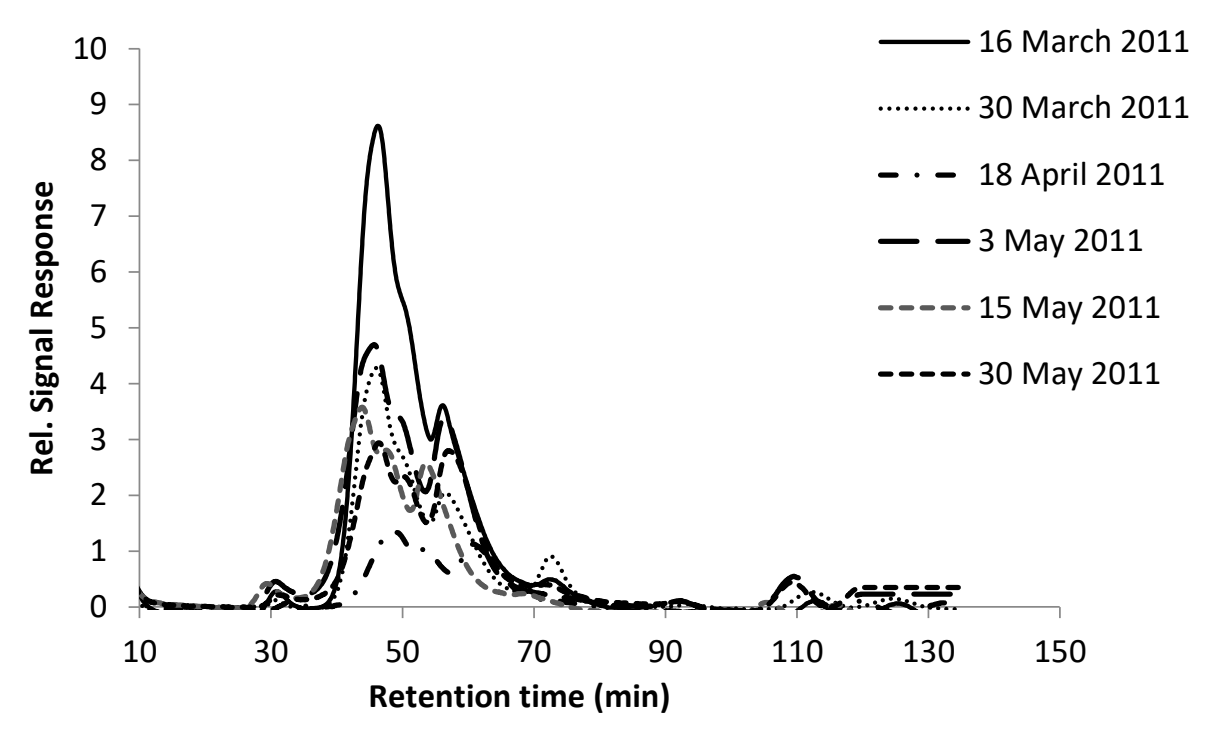

Figure 3. LC-OCD chromatogram of stormwater samples using organic carbon detector.

\subsection{Relationship between DOM, Its Fractions and Microbes}

A relationship between E. coli, Enterococcus spp. and DOM and its constituents was calculated using a power decay curve $\left(y=a+b x^{-c}\right)$ where $a, b$ and $c$ are constants (Figure 4). The plot shows a decrease in organic concentration, which favoured an increase in microbe numbers for both species with a non-linear trend. It is known that the fate of microorganisms in soil is governed by attachment or release from hydrological substrates and interactions. Pringle and Fletcher [46] found that a variety of macromolecules inhibited the attachment of bacteria to polystyrene when macromolecules were present in the suspension during the attachment period. Bales, et al. [47] showed that a higher soil organic carbon content retarded virus transport. Another study by Bales, Li, Maguire, Yahya and Gerba [12] showed that hydrophobic organic matter could delay virus transport in a column study. 

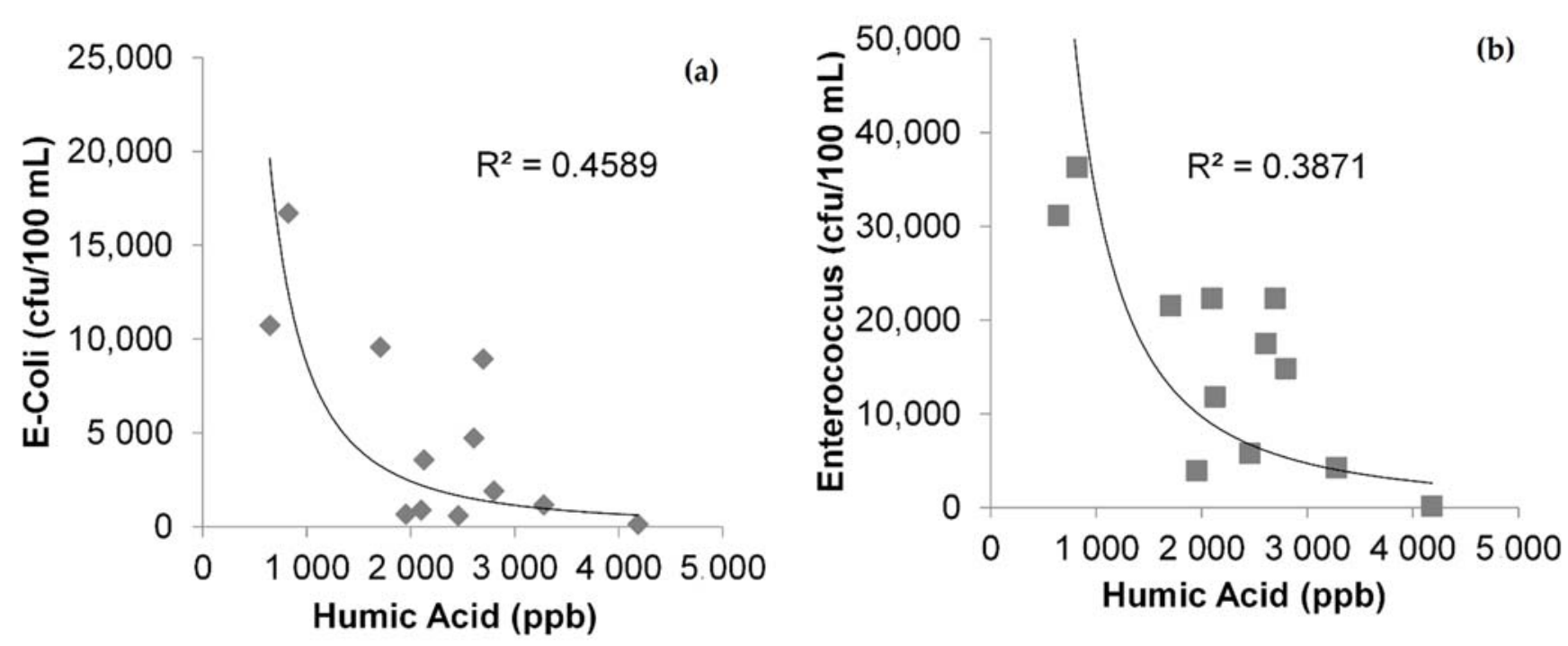

Figure 4. Relationship between E. coli (a), Enterococcus spp. (b) and dissolved organic carbon in stormwater.

The correlation coefficients calculated from non-linear regression (power curve) between E. coli and DOC, hydrophobic organic carbon (HOC, calculated as DOC minus CDOC)), chromatographic dissolved organic carbon (CDOC) and humic fractions are shown below in Table 1. This analysis shows that the hydrophobic fraction may have less influence on the mobility of E. coli and Enterococcus spp. compared to the hydrophilic fraction. As the hydrophobic fraction is less polar, it mainly interacts with microbes via adsorption [48-50]. Among the hydrophilic fractions, humic substances showed a negative correlation, indicating that their presence may disfavour FIB transport. The relationship between E. coli and Enterococcus spp. and DOC is plotted below.

Table 1. Relationship between dissolved organic matter and its fractions with faecal indicator bacteria (FIB) using the coefficient of determination $\left(\mathrm{R}^{2}\right)$ of a curve fitted with a power equation as described in the text.

\begin{tabular}{ccccc}
\hline & DOC & HOC & CDOC & Humic Acid \\
\hline E. coli & 0.34 & - & 0.35 & $0.46(p=0.0300)$ \\
\hline Enterococcus spp. & 0.36 & - & 0.46 & $0.39(p=0.0007)$ \\
\hline
\end{tabular}

\subsection{Relationship between Metal Ions and Microbes}

It has been mentioned in the literature that microbes exhibit a biphasic response to a number of metals in soil and water [51-53]. According to these studies, at lower concentrations, many metals stimulate the growth of microbes, but at higher concentrations, the growth is inhibited. Recent work has shown that microbial attachment to mineral surfaces may enhance metals solubility in aqueous environments by mobilising sorbed impurities from surface sites.

The plot in Figure 5 of the concentration of microbes against trivalent metal ions ( $\mathrm{Al}^{3+}$ and $\mathrm{Fe}^{3+}$ ) shows a good positive correlation between the metal ions and FIB numbers ( $p$ value $=0.01$ to 0.0007 ). The outcome reflected that a higher trivalent metal concentration could provide enough opportunity to microbes with metal ions, and thus could enhance the adherence of microbes to metals. This outcome is supported by several past studies and a number of possible explanations are proposed. We mentioned earlier that organic matter and microbes are negatively charged. The negative charge in the organic matter is by phenolic and carboxylic groups. In our study, we observed a zeta potential (electric potential between the surface of the particles in the suspending liquid) of stormwater of around -27 to $-17 \mathrm{mV}$. The higher value $(-27 \mathrm{mV})$ was observed when there was a low metal ion concentration in the samples. We also observed that when the metal 
ion concentration increased in the samples, the zeta potential of stormwater dropped (shifted towards zero). The downward trend of the zeta potential showed that NOM charge neutralisation occurred by increased metals in the runoff water. This means that a high concentration of metal ions present in stormwater (after NOM charge neutralisation) may have attracted negatively charged microbes and hence helped to increase the microbe concentration in the runoff. An experiment conducted by Elzinga, et al. [54] found that a long contact time between metal ions and microbes could help to adhere microbes on the metal ion particles. Liu, et al. [55] further says that the close contact between microbes and metal oxides facilitates electron flow between metal oxides and microbial cells and promote the adhesion. A positive role of bacterial transport by metal concentration has also been observed by Jewett, et al. [56]. They state that a higher ionic strength compresses the electric double layer and reduces electrostatic repulsion between like-charged particles at a given separation. Other investigators have observed similar changes in cell penetration as a function of metal ion concentration [8,57]. A study by Yee, et al. [58] suggested that the microbes and mineral ratio are important in the adsorption of microbes into metal particles. They say that the higher the ratio, the higher the adhesion.
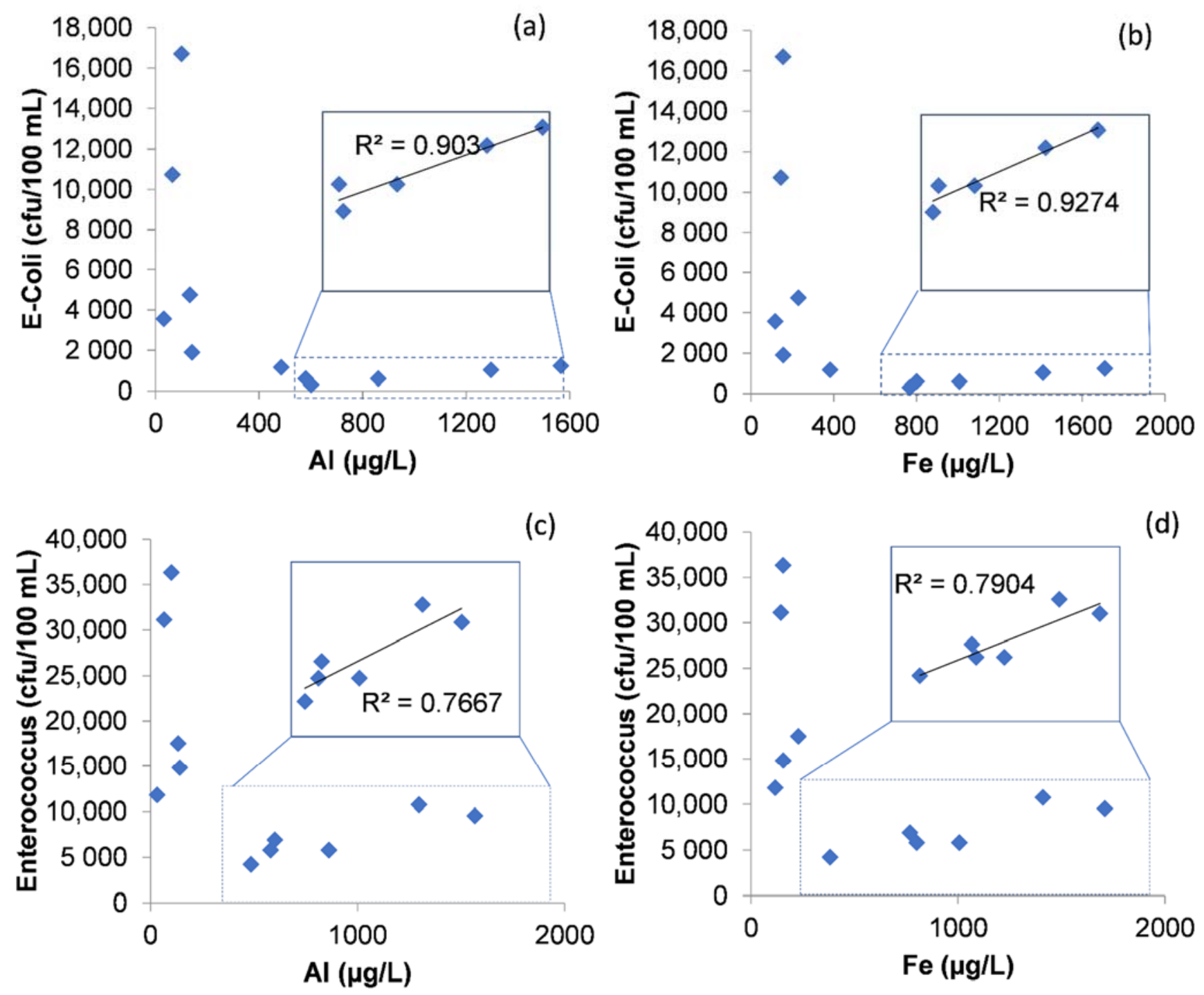

Figure 5. Relationship between metal ions and E. coli (a,b) and Enterococci spp. (c,d). 


\subsection{Relationship between Flow Rate and Microbes}

Total rainfall volume and rainfall intensity are important factors in the release of pathogens from faecal matter and the subsequent mobilisation into surface and ground water. Several publications have linked the incidence of rainfall and waterborne diseases around the world. Stumpf, Piehler, Thompson and Noble [29] demonstrated a very good relationship between E. coli and Enterococci spp. with stormwater runoff and hydrograph patterns in creek water in North Carolina. Cho, et al. [59] showed meteorological effects on the level of faecal indicator bacteria in Guanju Creek in South Korea, an urban stream. Figure 6 shows the relationship between FIB and flow rate, which we observed in the present study. The result suggested that the transfer of microbes from grassland soil to water could be associated with hydrological energy. Higher energy precipitation might have enabled the physical movement of microbes and their hosts, creating a rapid transfer. These observations and interpretations are in agreement with other studies that reported an increase in FIB with an increase in rainfall by several fold $[29,60]$.

E. coli

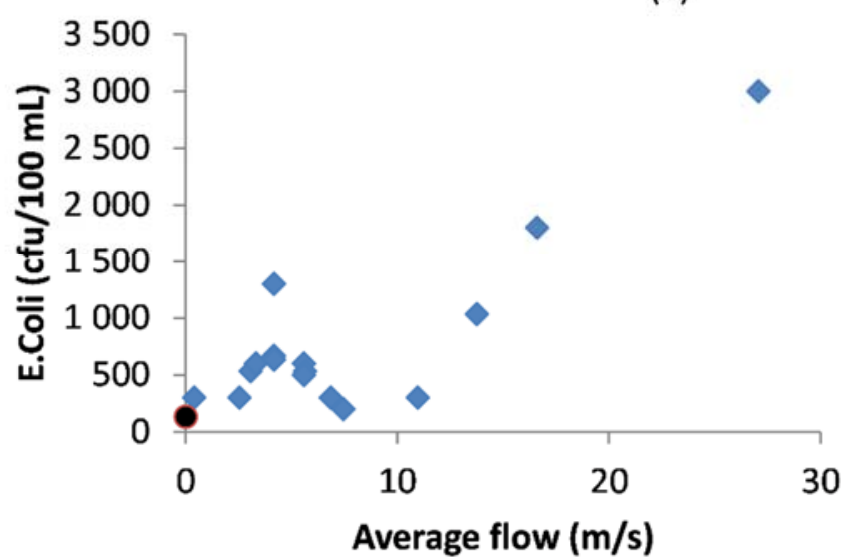

Enterococci

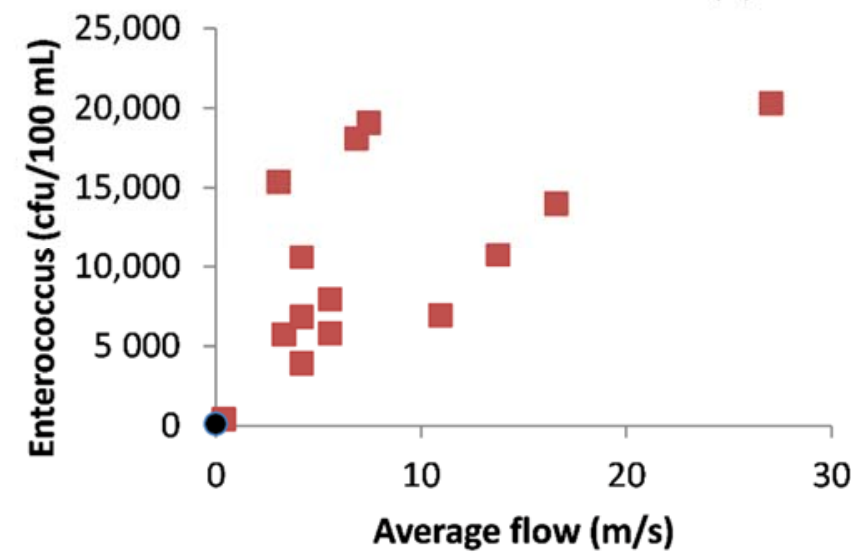

Figure 6. Relationship between flow rate and E. coli (a) and Enterococcos (b) (the black dots represent dry weather flow data).

\section{Conclusions}

Stormwater samples collected from a medium-density residential urban catchment in South East Queensland were analysed for faecal indicator bacteria (FIB) and their transport in relation with environmental variables such as dissolved organic carbon (DOC), metals and flow rate for twelve storm events. The result showed that the E. coli and Enterococcus spp. numbers varied between $10^{2}$ and $10^{4} / 100 \mathrm{~mL}$ during the dry and wet periods. The DOC in the stormwater samples was in the range of $2.2-7.7 \mathrm{mg} / \mathrm{L}$, in which the hydrophilic fraction constituted the highest mass fraction (60-80\%). A relationship between E. coli, Enterococcus spp. and DOM and its constituents showed a non-linear power decay trend. Further detailed analysis showed that within the hydrophilic fraction, the humic substances resisted the FIB transport more than the other organics. The lower heavy metal concentration did not dictate the transport of FIB, whereas at a higher concentration, it showed a linear relationship. The role of environmental variables in the motility of microorganisms in stormwater runoff is still unknown because the interactions and adhesion/repulsion of microbes with metal ions and natural organic matter are complex. Further research in this area may provide valuable tools to conduct risk assessment and better inform future management strategies on harvesting and reuse.

Author Contributions: Conceptualization, methodology, formal analysis, investigation, R.A., J.P.S.S., M.N.C., S.T. and W.G.; writing-original draft preparation, writing, reviewing and editing R.A., J.P.S.S., M.N.C., S.T. and W.G. and B.M. All authors have read and agreed to the published version of the manuscript. 
Funding: The research was funded by CRC for Water Sensitive Cities (www.watersensitivecities. org.au) and its funding bodies including the Australian Government and numerous partnering organizations; the Cities as Water Supply Catchments program, funded by the National Water Commission and the Victoria Smart Water Fund among many others; and the South East Queensland Urban Water Security Research Alliance (UWSRA), which is a scientific collaboration between the Queensland Government, CSIRO Water for a Healthy Country Flagship, The University of Queensland, and Griffith University.

Institutional Review Board Statement: Not applicable.

Informed Consent Statement: Not applicable.

Data Availability Statement: The data presented in this study are available on request from the corresponding author.

Acknowledgments: The authors acknowledge CRC for Water Sensitive Cities (www.watersensitivecities. org.au) and its funding bodies mentioned in Funding, CSIRO Water for a Healthy Country Flagship for sample collection, storage and microbial analysis, Advanced Water Management Centre the University of Queensland for providing chemical and instrumental laboratory facilities, ICP Elemental Analysis Laboratory, University of New South Wales for LCOCD analysis.

Conflicts of Interest: The authors declare no conflict of interest.

\section{References}

1. Aryal, R.K.; Lee, B.-K. Characteristics of Suspended Solids and Micropollutants in First-Flush Highway Runoff. Water Air Soil Pollut. Focus 2009, 9, 339-346. [CrossRef]

2. Sidhu, J.P.S.; Ahmed, W.; Gernjak, W.; Aryal, R.; McCarthy, D.; Palmer, A.; Kolotelo, P.; Toze, S. Sewage pollution in urban stormwater runoff as evident from the widespread presence of multiple microbial and chemical source tracking markers. Sci. Total. Environ. 2013, 463-464, 488-496. [CrossRef] [PubMed]

3. Sidhu, J.P.S.; Ahmed, W.; Hodgers, L.; Toze, S. Occurrence of Virulence Genes Associated with Diarrheagenic Pathotypes in Escherichia coli Isolates from Surface Water. Appl. Environ. Microbiol. 2013, 79, 328-335. [CrossRef]

4. Sidhu, J.P.S.; Skelly, E.; Hodgers, L.; Ahmed, W.; Li, Y.; Toze, S. Prevalence ofEnterococcusSpecies and Their Virulence Genes in Fresh Water Prior to and after Storm Events. Environ. Sci. Technol. 2014, 48, 2979-2988. [CrossRef]

5. Tiefenthaler, L.; Stein, E.D.; Schiff, K. Origins and Mechanisms of Watershed and Land Use Based Sources of Fecal Indicator Bacteria in Urban Stormwater; Southern California Coastal Water Research Project 2008 Annual Report; SCCWRP: Costa Mesa, CA, USA, 2008; pp. 153-161.

6. Thériault, A.; Duchesne, S. Quantifying the Fecal Coliform Loads in Urban Watersheds by Hydrologic/Hydraulic Modeling: Case Study of the Beauport River Watershed in Quebec. Water 2015, 7, 615-633. [CrossRef]

7. Soupir, M.L.; Mostaghimi, S.; Dillaha, T. Attachment of Escherichia coli and Enterococci to Particles in Runoff. J. Environ. Qual. 2010, 39, 1019-1027. [CrossRef] [PubMed]

8. Fontes, D.; Mills, A.L.; Hornberger, G.M.; Herman, J.S. Physical and chemical factors influencing transport of microorganisms through porous media. Appl. Environ. Microbiol. 1991, 57, 2473-2481. [CrossRef]

9. Yang, H.; Kim, H.; Tong, M. Influence of humic acid on the transport behavior of bacteria in quartz sand. Colloids Surf. B Biointerfaces 2012, 91, 122-129. [CrossRef]

10. Fletcher, M.; Marshall, K.C. Are Solid Surfaces of Ecological Significance to Aquatic Bacteria? In Advances in Microbial Ecology; Marshall, K.C., Ed.; Springer: Heidelberg, Germany, 1982; Volume 6, pp. 199-236.

11. Richardson, R.; Mills, A.; Herman, J.; Hornberger, G. Effect of humic material on interactions between bacterial cells and mineral surfaces. LMECOL Contrib. 2000, 1, 1-7.

12. Bales, R.C.; Li, S.; Maguire, K.M.; Yahya, M.T.; Gerba, C.P. MS-2 and poliovirus transport in porous media: Hydrophobic effects and chemical perturbations. Water Resour. Res. 1993, 29, 957-963. [CrossRef]

13. Atherholt, T.B.; Lechevallier, M.W.; Norton, W.D.; Rosen, J.S. Effect of rainfall on Giardia and crypto. J. Am. Water Work. Assoc. 1998, 90, 66-80. [CrossRef]

14. Lipp, E.K.; Kurz, R.; Vincent, R.; Rodriguez-Palacios, C.; Farrah, S.R.; Rose, J.B. The Effects of Seasonal Variability and Weather on Microbial Fecal Pollution and Enteric Pathogens in a Subtropical Estuary. Estuaries 2001, 24, 266-276. [CrossRef]

15. Thurman, R.; Faulkner, B.; Veal, D.; Cramer, G.; Meiklejohn, M. Water quality in rural Australia. J. Appl. Microbiol. 1998, 84, 627-632. [CrossRef]

16. Schaldach, C.; Bourcier, W.L.; Shaw, H.F.; Viani, B.E.; Wilson, W. The influence of ionic strength on the interaction of viruses with charged surfaces under environmental conditions. J. Colloid Interface Sci. 2006, 294, 1-10. [CrossRef] [PubMed]

17. Walshe, G.E.; Pang, L.; Flury, M.; Close, M.E.; Flintoft, M. Effects of pH, ionic strength, dissolved organic matter, and flow rate on the co-transport of MS2 bacteriophages with kaolinite in gravel aquifer media. Water Res. 2010, 44, 1255-1269. [CrossRef] 
18. McCarthy, D.; Hathaway, J.; Hunt, W.; Deletic, A. Intra-event variability of Escherichia coli and total suspended solids in urban stormwater runoff. Water Res. 2012, 46, 6661-6670. [CrossRef] [PubMed]

19. Niazi, M.; Obropta, C.; Miskewitz, R. Pathogen transport and fate modeling in the Upper Salem River Watershed using SWAT model. J. Environ. Manag. 2015, 151, 167-177. [CrossRef]

20. Aryal, R.; Furumai, H.; Nakajima, F.; Boller, M. Dynamic behavior of fractional suspended solids and particle-bound polycyclic aromatic hydrocarbons in highway runoff. Water Res. 2005, 39, 5126-5134. [CrossRef]

21. Murphy, L.U.; Cochrane, T.A.; O'Sullivan, A. Build-up and wash-off dynamics of atmospherically derived Cu, Pb, Zn and TSS in stormwater runoff as a function of meteorological characteristics. Sci. Total Environ. 2015, 508, 206-213. [CrossRef]

22. Reitz, A.; Hemric, E.; Hall, K.K. Evaluation of a multivariate analysis modeling approach identifying sources and patterns of nonpoint fecal pollution in a mixed use watershed. J. Environ. Manag. 2021, 277, 111413. [CrossRef]

23. Chen, H.J.; Chang, H. Response of discharge, TSS, and E. coli to rainfall events in urban, suburban, and rural watersheds. Environ. Sci. Process. Impacts 2014, 16, 2313-2324. [CrossRef]

24. Hathaway, J.M.; Hunt, W.F.; McCarthy, D.T. Variability of Intra-event Statistics for Multiple Fecal Indicator Bacteria in Urban Stormwater. Water Resour. Manag. 2015, 29, 3635-3649. [CrossRef]

25. Zhuang, J.; Jin, Y. Virus Retention and Transport as Influenced by Different Forms of Soil Organic Matter. J. Environ. Qual. 2003, 32, 816-823. [CrossRef]

26. Anesio, A.M.; Hollas, C.; Granéli, W.; Laybourn-Parry, J. Influence of Humic Substances on Bacterial and Viral Dynamics in Freshwaters. Appl. Environ. Microbiol. 2004, 70, 4848-4854. [CrossRef]

27. Cho, K.H.; Pachepsky, Y.A.; Oliver, D.M.; Muirhead, R.W.; Park, Y.; Quilliam, R.S.; Shelton, D.R. Modeling fate and transport of fecally-derived microorganisms at the watershed scale: State of the science and future opportunities. Water Res. 2016, 100, 38-56. [CrossRef] [PubMed]

28. Guiné, V.; Martins, J.; Gaudet, J.P. Facilitated transport of heavy metals by bacterial colloids in sand columns. In Journal de Physique IV (Proceedings); EDP Sciences: Les Ulis, France, 2003; Volume 107, pp. 593-596.

29. Stumpf, C.H.; Piehler, M.F.; Thompson, S.; Noble, R.T. Loading of fecal indicator bacteria in North Carolina tidal creek headwaters: Hydrographic patterns and terrestrial runoff relationships. Water Res. 2010, 44, 4704-4715. [CrossRef] [PubMed]

30. Schillinger, J.E.; Gannon, J.J. Bacterial adsorption and suspended particles in urban stormwater. J. Water Pollut. Control Fed. 1985, $57,384-389$.

31. Hornberger, G.M.; Mills, A.L.; Herman, J.S. Bacterial transport in porous media: Evaluation of a model using laboratory observations. Water Resour. Res. 1992, 28, 915-923. [CrossRef]

32. Sidhu, J.; Hodgers, L.; Ahmed, W.; Chong, M.; Toze, S. Prevalence of human pathogens and indicators in stormwater runoff in Brisbane, Australia. Water Res. 2012, 46, 6652-6660. [CrossRef]

33. Lange, B.; Strathmann, M.; Oßmer, R. Performance validation of chromogenic coliform agar for the enumeration of Escherichia coli and coliform bacteria. Lett. Appl. Microbiol. 2013, 57, 547-553. [CrossRef]

34. Tiefenthaler, L.L.; Stein, E.D.; Lyon, G.S. Fecal indicator bacteria (FIB) levels during dry weather from Southern California reference streams. Environ. Monit. Assess. 2009, 155, 477-492. [CrossRef] [PubMed]

35. Desai, A.M.; Rifai, H.S. Variability of Escherichia coli Concentrations in an Urban Watershed in Texas. J. Environ. Eng. 2010, 136, 1347-1359. [CrossRef]

36. Tiefenthaler, L.; Stein, E.D.; Schiff, K.C. Levels and patterns of fecal indicator bacteria in stormwater runoff from homogenous land use sites and urban watersheds. J. Water Health 2010, 9, 279-290. [CrossRef] [PubMed]

37. Zsolnay, Á. Dissolved organic matter: Artefacts, definitions, and functions. Geoderma 2003, 113, 187-209. [CrossRef]

38. Zhao, C.; Wang, C.-C.; Li, J.-Q.; Wang, C.-Y.; Wang, P.; Pei, Z.-J. Dissolved organic matter in urban stormwater runoff at three typical regions in Beijing: Chemical composition, structural characterization and source identification. RSC Adv. 2015, 5, 73490-73500. [CrossRef]

39. Aryal, R.; Grinham, A.; Beecham, S. Insight into dissolved organic matter fractions in Lake Wivenhoe during and after a major flood. Environ. Monit. Assess. 2016, 188, 1-11. [CrossRef]

40. Zazouli, M.; Nasseri, S.; Mahvi, A.; Mesdaghinia, A.; Younecian, M.; Gholami, M. Determination of hydrophobic and hy-drophilic fractions of natural organic matter in raw water of Jalalieh and Tehranspars water treatment plants (Tehran). J. Appl. Sci. 2007, 7, 2651-2655. [CrossRef]

41. Provenzano, M.R.; Cilenti, A.; Gigliotti, G.; Senesi, N. Spectroscopic Investigation on Hydrophobic and Hydrophilic Fractions of Dissolved Organic Matter Extracted from Soils at Different Salinities. CLEAN Soil Air Water 2008, 36, 748-753. [CrossRef]

42. Mozes, N.; Marchal, F.; Hermesse, M.P.; Van Haecht, J.L.; Reuliaux, L.; Léonard, A.J.; Rouxhet, P.G. Immobilization of microorganisms by adhesion: Interplay of electrostatic and nonelectrostatic interactions. Biotechnol. Bioeng. 1987, 30, 439-450. [CrossRef] [PubMed]

43. Schijven, J.F.; Hassanizadeh, S.; de Bruin, R.H. Two-site kinetic modeling of bacteriophages transport through columns of saturated dune sand. J. Contam. Hydrol. 2002, 57, 259-279. [CrossRef]

44. Scholl, M.A.; Mills, A.L.; Herman, J.S.; Hornberger, G.M. The influence of mineralogy and solution chemistry on the attachment of bacteria to representative aquifer materials. J. Contam. Hydrol. 1990, 6, 321-336. [CrossRef]

45. Mills, A.L.; Herman, J.S.; Hornberger, G.M.; DeJesús, T.H. Effect of Solution Ionic Strength and Iron Coatings on Mineral Grains on the Sorption of Bacterial Cells to Quartz Sand. Appl. Environ. Microbiol. 1994, 60, 3300-3306. [CrossRef] [PubMed] 
46. Pringle, J.H.; Fletcher, M. Influence of substratum hydration and adsorbed macromolecules on bacterial attachment to surfaces. Appl. Environ. Microbiol. 1986, 51, 1321-1325. [CrossRef] [PubMed]

47. Bales, R.C.; Hinkle, S.R.; Kroeger, T.W.; Stocking, K.; Gerba, C.P. Bacteriophage adsorption during transport through porous media: Chemical perturbations and reversibility. Environ. Sci. Technol. 1991, 25, 2088-2095. [CrossRef]

48. Baughman, G.L.; Paris, D.F.; Hodson, R.E. Microbial Bioconcentration of Organic Pollutants from Aquatic Systems-A Critical Review. CRC Crit. Rev. Microbiol. 1981, 8, 205-228. [CrossRef] [PubMed]

49. Magnusson, K. Hydrophobic interaction-a mechanism of bacterial binding. Scand. J. Infect. Dis. Suppl. 1982, 33, 32-36.

50. Kefford, B.; Marshall, K.C. The role of bacterial surface and substratum hydrophobicity in adhesion of Leptospira biflexa serovarpatoc 1 to inert surfaces. Microb. Ecol. 1986, 12, 315-322. [CrossRef]

51. Sadler, W.R.; Trudinger, P.A. The inhibition of microorganisms by heavy metals. Miner. Deposita 1967, 2, 158-168. [CrossRef]

52. Loveless, J.E.; Painter, H.A. The Influence of Metal Ion Concentrations and pH Value on the Growth of a Nitrosomonas Strain Isolated from Activated Sludge. J. Gen. Microbiol. 1968, 52, 1-14. [CrossRef]

53. Cho, K.S.; So, Y.K.; Ji, Y.K.; Hee, W.R. Quantification of inhibitory impact of heavy metals on the growth of Escherichia Coli. Korean J. Microbiol. Biotechnol. 2004, 32, 341-346.

54. Elzinga, E.J.; Huang, J.-H.; Chorover, J.; Kretzschmar, R. ATR-FTIR Spectroscopy Study of the Influence of pH and Contact Time on the Adhesion ofShewanella putrefaciensBacterial Cells to the Surface of Hematite. Environ. Sci. Technol. 2012, 46, 12848-12855. [CrossRef]

55. Liu, Z.; Wang, H.; Li, J.; Hong, Z.; Xu, R. Adhesion of Escherichia coli and Bacillus subtilis to amorphous Fe and Al hydroxides and their effects on the surface charges of the hydroxides. J. Soils Sediments 2015, 15, 2293-2303. [CrossRef]

56. Jewett, D.G.; Hilbert, T.A.; Logan, B.E.; Arnold, R.G.; Bales, R.C. Bacterial transport in laboratory columns and filters: Influence of ionic strength and $\mathrm{pH}$ on collision efficiency. Water Res. 1995, 29, 1673-1680. [CrossRef]

57. Gannon, J.; Tan, Y.H.; Baveye, P.; Alexander, M. Effect of sodium chloride on transport of bacteria in a saturated aquifer material. Appl. Environ. Microbiol. 1991, 57, 2497-2501. [CrossRef]

58. Yee, N.; Fein, J.B.; Daughney, C.J. Experimental study of the $\mathrm{pH}$, ionic strength, and reversibility behavior of bacteria-mineral adsorption. Geochim. Cosmochim. Acta 2000, 64, 609-617. [CrossRef]

59. Cho, K.H.; Cha, S.M.; Kang, J.-H.; Lee, S.W.; Park, Y.; Kim, J.-W.; Kim, J.H. Meteorological effects on the levels of fecal indicator bacteria in an urban stream: A modeling approach. Water Res. 2010, 44, 2189-2202. [CrossRef] [PubMed]

60. Rodgers, P.; Soulsby, C.; Hunter, C.; Petry, J. Spatial and temporal bacterial quality of a lowland agricultural stream in northeast Scotland. Sci. Total Environ. 2003, 314-316, 289-302. [CrossRef] 